\title{
The use of cyanoacrylate for mesh fixation in inguinal hernia repair - literature review
}

\author{
Mircea LICA ${ }^{1}, \mathrm{MD}$, Victor Gheorghe RADU ${ }^{1}, \mathrm{MD}$, Alexandru CHIOTOROIU ${ }^{2}, \mathrm{MD}$, \\ Prof. Mircea BEURAN², MD, PhD \\ ${ }^{1}$ General Surgery Department, Life Memorial Hospital, Bucharest \\ ${ }^{2}$ General Surgery Department, Clinical Emergency Hospital, Bucharest
}

\begin{abstract}
Introduction. Surgical mesh procedures addressed to inguinal hernia leads to better results in term of recurrence, but the problems of postoperative pain still remains, and mesh fixation is considered to be one of the factors. Our objective is to determine the impact of cyanoacrylate glues for mesh fixation in clinical results considering postoperative acute and chronic pain, complications and recurrence.

Material and methods. We performed a systematic review of literature, searching for "cyanoacrylates" (MeSH Terms) AND "hernia" (MeSH Terms) AND "herniorrhaphy" (MeSH Terms) in order to find papers that discuss the use of cyanoacrylate glues in mesh fixation for hernia repair.

Results. We found 27 articles: 17 randomized trials (RT), 8 case series, 1 review and 1 meta-analysis. The authors of these papers come from only two regions: Europe and Asia.

4 surgical procedures were used in combinations with cyanoacrylate mesh fixation: Lichtenstein, plug and patch technique, TAPP and TEP.

No studies showed the inferiority of glue over the other methods of fixation considering all four postoperative outcomes (acute pain, complication, chronic pain and recurrence).

The synthetic glue fixation achieves better results in terms of acute and chronic pain for both open and minimally-invasive surgical procedures for inguinal hernia repair.

Conclusions. Although synthetic glue mesh fixation for inguinal hernia is not widely used over the world, it is a safe and effective way for mesh fixation both in open and minimally-invasive inguinal hernia repair and significantly decreases postoperative acute and chronic pain.
\end{abstract}

Keywords: inguinal hernia, mesh, cyanoacrylate, review

\section{INTRODUCTION}

Inguinal hernia is a wide-spread problem which affects almost $25 \%$ of men during their life-time (1).

Multiple surgical procedures have been developed to address this condition and in recent years, ones using meshes proved to have better results than tissue repairs in terms of hernia recurrence and compliance to the procedure.
Nevertheless, mesh fixation is still under debate. Today there are multiple options which vary from no-fixation to sutures, permanent or absorbable tackers, self-fixating mesh to biological or synthetic glues.

Our objective is to determine the spread of cyanoacrylate glue usage for inguinal hernia mesh fixation and the clinical results in terms of postoperative pain, complications, chronic pain and hernia recurrence. 


\section{METHODS}

Systematic review of the literature with US National Library of Medicine and National Institutes of Health International PubMed using abstracts and articles available in PubMed and Cochrane databases, searching for ("cyanoacrylates" (MeSH Terms) OR "cyanoacrylates" (All Fields) OR "cyanoacrylate" (All Fields)) AND ("hernia" (MeSH Terms) OR "hernia" (All Fields) AND "herniorrhaphy" (MeSH Terms) OR "herniorrhaphy" (All Fields))

Our focus is on adult inguinal hernia repair by a surgical procedure using a mesh. We take into consideration all the studies without a time limit, but we analyzed only the ones designed for humans and written in the English language; we include both the ones with an abstract or full-text available.

All the remaining articles after the electronic filters were applied were individually reviewed by the authors to meet the including criteria and provide the information needed to fulfil our objective.

\section{RESULTS AND DISCUSSION}

The first electronic search returned 462 articles and 21 duplicates were removed. 411 of the remaining papers were excluded according to our criteria following manual screening. From the remaining 30 articles three were not taken into consideration as they couldn't provide most of the data needed. The study flow dia- gram is represented in Fig. 1 and was created using PRISMA Guideline (2).

27 articles met the selection criteria and were written by 26 authors. These papers and their main characteristics are summarized in Table 1.

The authors of the articles come from only two regions: Europe (19 authors - 73\%) and Asia (7 authors $-27 \%$ ) - Fig. 2. There isn't a large spread of this method around the globe as three quarters of the reporting surgeons are working in Europe. Even here most of the reports come from only four countries: Switzerland, Spain, Italy and Poland.

Cyanoacrylate is the generic name of a group of fast-acting adhesives such as ethyl-2-cyanoacrylate, n-butyl cyanoacrylate, 2-octyl cyanoacrylate. Cyanoacrylate is an acrylic resin that polymerizes exothermically in the presence of water, especially with hydroxide ions, joining the bonded surfaces in 5-6 $\mathrm{s}$ and reaching the final stage in 60s. It bonds body tissue excellently and shows bacteriostatic effects. The use of such synthetic glues has become general practice and they are used today in surgery, digestive endoscopy or vascular interventional radiology. The n-butyl-2-cyanoacrylate (NBCA) is the most used glue for mesh fixation in hernia repair and it is produced under different brand names (Histoacryl and Glubran are the most well-known in Europe).

NBCA glue was used for mesh fixation in 24 out of 26 articles (92.3\%).

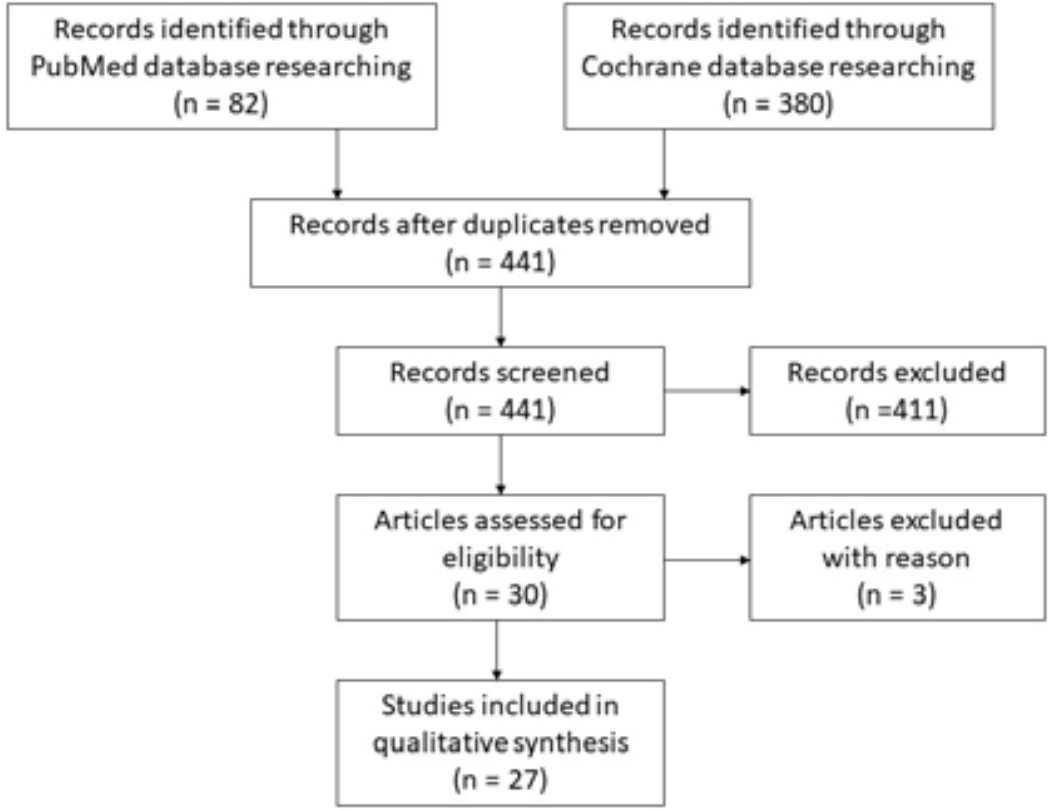

FIGURE 1. Study flow diagram 
TABLE 1

\begin{tabular}{|c|c|c|c|c|c|c|c|}
\hline & Year & Author & Country & Study & Procedure & Glue & Comparison \\
\hline 1 & 2017 & Liew W (3) & Malaysia & RT & TEP & NBCA & Glue vs Tackers \\
\hline 2 & 2017 & Shen YM (4) & China & RT & TEP & NBCA & Glue vs No-fixation \\
\hline 3 & 2017 & Hoyuela C (5) & Spain & RT & Lichtenstein & NBCA & Glue vs Suture \\
\hline 4 & 2017 & Matikainen M (6) & Finland & RT & Lichtenstein & NBCA & Glue vs Suture \\
\hline 5 & 2016 & Antoniou SA (7) & Germany & $\begin{array}{l}\text { Meta- } \\
\text { Analysis }\end{array}$ & TAPP/TEP & $\begin{array}{c}\text { cyanoacrylate } \\
\text { fibrin }\end{array}$ & Glue vs mechanical fixation \\
\hline 6 & 2016 & Jani K (8) & India & RT & TEP & NBCA & Glue vs suture \\
\hline 7 & 2015 & Rönkä K (9) & Finland & RT & Lichtenstein & NBCA & $\begin{array}{l}\text { Glue vs Self-grip mesh vs } \\
\text { Suture }\end{array}$ \\
\hline 8 & 2014 & Garcia-Vallejo L (10) & Spain & Case series & TEP & NBCA & 61 consecutive case series \\
\hline 9 & 2014 & $\begin{array}{l}\text { Moreno-Egea A } \\
(11)\end{array}$ & Spain & RT & TEP/Lichtenstein & $\begin{array}{c}\mathrm{n} \text {-hexyl- } \alpha- \\
\text { cyanoacrylate }\end{array}$ & $\begin{array}{l}\text { Glue vs sutures glue vs } \\
\text { tackers }\end{array}$ \\
\hline 10 & 2014 & Burza A (12) & Italy & Case series & TAPP & NBCA & Glue vs tackers \\
\hline 11 & 2014 & Sanders DL (13) & UK & Review & Lichtenstein & NBCA & $\begin{array}{l}\text { Glues, self-grip mesh, } \\
\text { tacks, suture }\end{array}$ \\
\hline 12 & 2013 & $\begin{array}{l}\text { Subwongcharoen } \\
\text { S (14) }\end{array}$ & Thailand & RT & TEP & NBCA & Glue vs tackers \\
\hline 13 & 2013 & $\begin{array}{l}\text { Moreno-Egea A } \\
(15)\end{array}$ & Spain & Case series & TEP/Lichtenstein & $\begin{array}{c}\text { n-hexyl- } \alpha- \\
\text { cyanoacrylate }\end{array}$ & Glue vs suture \\
\hline 14 & 2013 & Wang MG (16) & China & Case series & TAPP & NBCA & Glue vs tackers \\
\hline 15 & 2012 & $\begin{array}{l}\text { Eldabe Mikhail A } \\
\text { (17) }\end{array}$ & Spain & RT & Plug and patch & NBCA & Glue vs suture \\
\hline 16 & 2012 & $\begin{array}{l}\text { Treepongkaruna } \\
\text { SA (18) }\end{array}$ & Thailand & Case series & TEP & NBCA & 15 case series \\
\hline 17 & 2012 & Dabrowiecki S (19) & Poland & RT & Lichtenstein & NBCA & Glue vs suture \\
\hline 18 & 2012 & Shen YM (20) & China & RT & Lichtenstein & NBCA & Glue vs suture \\
\hline 19 & 2012 & Brügger L (21) & Switzerland & RT & TAPP & NBCA & Glue vs tackers \\
\hline 20 & 2012 & Kukleta JF (22) & Switzerland & Case series & TAPP & NBCA & 1336 case series \\
\hline 21 & 2012 & Kim-Fuchs C (23) & Switzerland & RT & Lichtenstein & NBCA & Glue vs suture \\
\hline 22 & 2011 & Paajanen H (24) & Finland & RT & Lichtenstein & NBCA & Glue vs suture \\
\hline 23 & 2010 & Testini M (25) & Italy & RT & Plug and Mesh & NBCA & Glue vs fibrin vs suture \\
\hline 24 & 2007 & Agresta F (26) & Italy & Case series & TAPP & NBCA & $\begin{array}{l}76 \text { case series glue and } \\
\text { fibrin }\end{array}$ \\
\hline 25 & 2004 & Nowobilski W (27) & Poland & RT & Lichtenstein & NBCA & Glue vs suture \\
\hline 26 & 2003 & Helbling C (28) & Switzerland & $\mathrm{RT}$ & Lichtenstein & NBCA & Glue vs suture \\
\hline 27 & 1998 & Jourdan IC (29) & UK & Case series & TAPP & NBCA & 7 case report \\
\hline
\end{tabular}

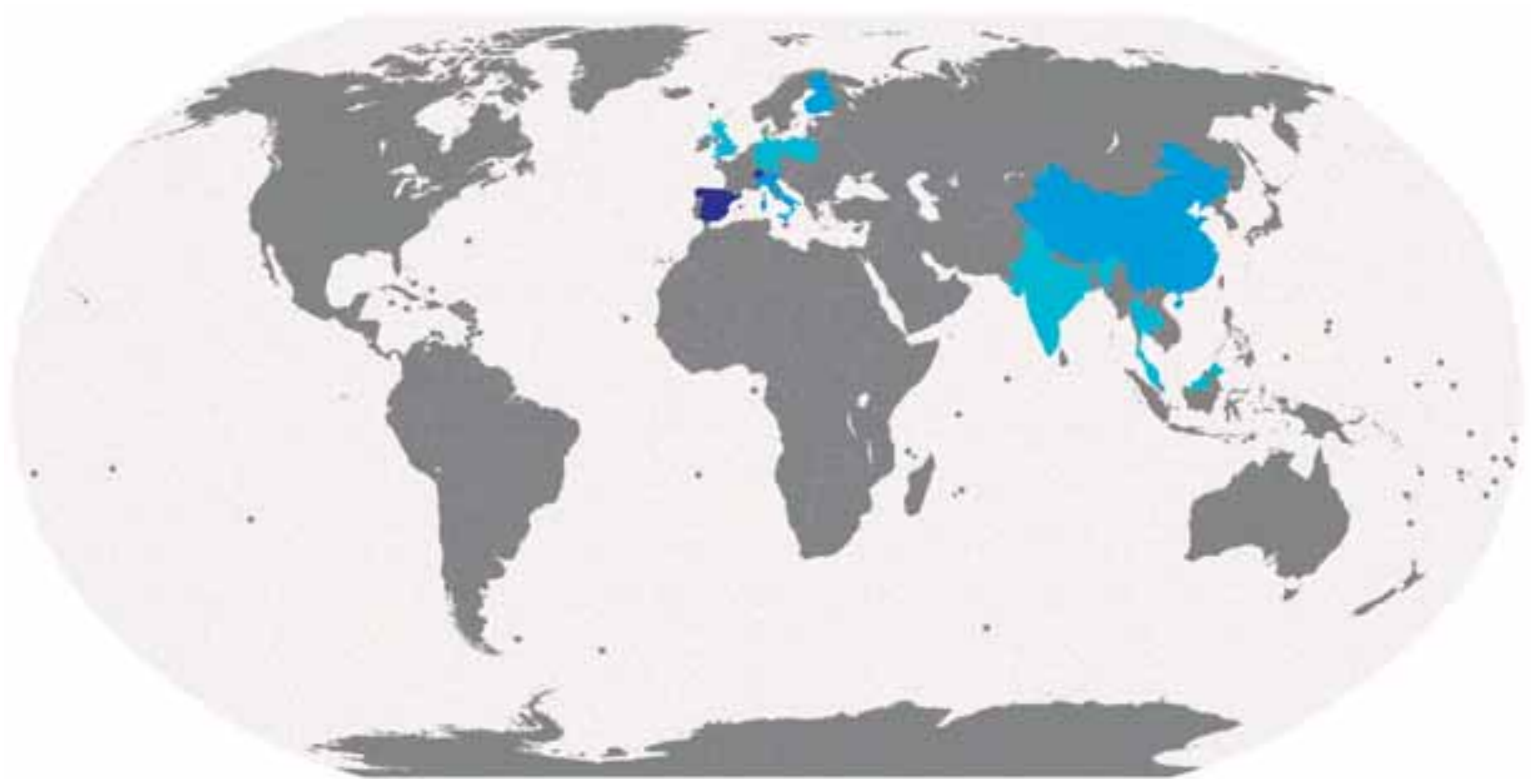

FIGURE 2. The world distribution of authors (the map was created using GunnMap application) 
The first article mentioning the use of cyanoacrylate for mesh fixation in laparoscopic hernia repair was in 1998 and the authors (Jourdan and Bailey) described the prototype glue dispenser and the application method (29).

After that pioneer report it took almost 10 years for the next article to be published. In 2007, Agresta, an Italian author, presented a series of 76 patients operated for inguinal hernia using a light mesh fixed by glues (fibrin sealant and n-butyl-2-cyanoacrylate) (26). The definitive acknowledgement of this method came in 2012 when Kukleta communicated positive results using $n$-butyl-cyanoacrylate glue to fix meshes in over 1300 TAPP repairs of primary and recurrent inguinal hernias (22). This is the largest series published so far in the literature.

The first meta-analysis of randomized trials comparing glues (both fibrin and biosynthetic) versus mechanical fixation in laparoscopic inguinal hernia repair was published in 2016 by Antoniou (7).

Today the recommended surgical procedures for inguinal hernia use a mesh. For the open access Lichtenstein is the choice procedure and for minimally invasive approach both TAPP (transab- dominal preperitoneal) and TEP (total extraperitoneal) are accepted with equal results (30).

Because there are different techniques the results were analyzed according to each procedure.

\section{Open hernia repair}

We identified 9 randomized trials (RT) from 2003 to 2017 which compare the use of NBCA and sutures for Lichtenstein hernia repair and the results are presented in Table 2 .

Considering acute pain in the immediate postoperative period the NBCA produce less pain in $5 \mathrm{RT}$ and similar pain in $3 \mathrm{RT}$ compared to sutures. The sutures used for comparison were absorbable (5 RT) and non-absorbable (4 RT). Chronic pain is defined as postoperative pain lasting more than 3 months. NBCA produce similar chronic pain as suture (7 RT) or less (1 RT).

Regarding postoperative complication the use of NCBA produce similar events ( $8 \mathrm{RT}$ ) or less (1 RT).

Hernia recurrence was equal (4 RT) or similar (5 RT) for both groups regardless of short term (3-5 months) or long term (5-7 years) follow-up.

TABLE 2. RT comparing NBCA in Lichtenstein hernia repair

\begin{tabular}{|c|c|c|c|c|c|c|c|c|c|}
\hline & Author/year & Study & $\begin{array}{l}\mathrm{Pt} \\
(\mathrm{n})\end{array}$ & Comparison & $\begin{array}{l}\text { Acute } \\
\text { pain }\end{array}$ & Complications & $\begin{array}{c}\text { Chronic } \\
\text { pain }\end{array}$ & Recurrence & Other \\
\hline 1 & $\begin{array}{l}\text { Hoyuela C, } \\
2017\end{array}$ & $\mathrm{RT}$ & 370 & $\begin{array}{c}\text { NBCA vs } \\
\text { perm. suture }\end{array}$ & $\begin{array}{l}\text { Favor } \\
\text { glue }\end{array}$ & Similar & Similar & $\begin{array}{c}\text { Similar } \\
\text { 1-year } \\
\text { follow-up }\end{array}$ & $\begin{array}{l}\text { Less operative } \\
\text { time in glue }\end{array}$ \\
\hline 2 & $\begin{array}{l}\text { Matikainen M, } \\
2017\end{array}$ & RT & 236 & $\begin{array}{l}\text { NBCA vs } \\
\text { abs. suture }\end{array}$ & Not done & $\begin{array}{c}\text { Similar } \\
\text { long-term } \\
\text { complication }\end{array}$ & Similar & $\begin{array}{l}\text { Similar } \\
\text { 7-year } \\
\text { follow-up }\end{array}$ & $\begin{array}{l}\text { Equal foreign } \\
\text { body sensation }\end{array}$ \\
\hline 3 & $\begin{array}{l}\text { Rönkä K, } \\
2015\end{array}$ & RT & 625 & $\begin{array}{l}\text { NBCA vs SG } \\
\text { mesh } \\
\text { vs perm. } \\
\text { suture }\end{array}$ & Similar & Similar & Similar & $\begin{array}{l}\text { Similar } \\
\text { 1-year } \\
\text { follow-up }\end{array}$ & $\begin{array}{l}\text { Equal foreign } \\
\text { body sensation }\end{array}$ \\
\hline 4 & $\begin{array}{l}\text { Dabrowiecki S, } \\
2012\end{array}$ & $\mathrm{RT}$ & 41 & $\begin{array}{c}\text { NBCA vs } \\
\text { perm. suture }\end{array}$ & $\begin{array}{l}\text { Favor } \\
\text { glue }\end{array}$ & Similar & Similar & $\begin{array}{c}\text { Similar } \\
\text { 1-year } \\
\text { follow-up }\end{array}$ & $\begin{array}{l}\text { Quicker return to } \\
\text { activity for glue }\end{array}$ \\
\hline 5 & $\begin{array}{l}\text { Shen YM, } \\
2012\end{array}$ & RT & 110 & $\begin{array}{c}\text { NBCA vs } \\
\text { perm. suture }\end{array}$ & $\begin{array}{l}\text { Favor } \\
\text { glue }\end{array}$ & Favor glue & $\begin{array}{l}\text { Favor } \\
\text { glue }\end{array}$ & Equal & $\begin{array}{l}\text { Less operative } \\
\text { time in glue }\end{array}$ \\
\hline 6 & $\begin{array}{l}\text { Kim-Fuchs C, } \\
2012\end{array}$ & $\mathrm{RT}$ & 264 & $\begin{array}{l}\text { NBCA vs } \\
\text { abs. suture }\end{array}$ & Similar & Similar & Similar & $\begin{array}{c}\text { Similar } \\
5 \text {-years } \\
\text { follow-up }\end{array}$ & $\begin{array}{l}\text { Less operative } \\
\text { time in glue }\end{array}$ \\
\hline 7 & $\begin{array}{l}\text { Paajanen H, } \\
2011\end{array}$ & RT & 302 & $\begin{array}{l}\text { NBCA vs } \\
\text { abs. suture }\end{array}$ & Similar & Similar & Similar & $\begin{array}{c}\text { Equal } \\
\text { 1-year } \\
\text { follow-up }\end{array}$ & $\begin{array}{l}\text { Similar operative } \\
\text { time }\end{array}$ \\
\hline 8 & $\begin{array}{l}\text { Nowobilski W, } \\
2003\end{array}$ & RT & 46 & $\begin{array}{l}\text { NBCA vs } \\
\text { abs. suture }\end{array}$ & $\begin{array}{l}\text { Favor } \\
\text { glue }\end{array}$ & Similar & Not done & $\begin{array}{c}\text { Equal } \\
4,7-\text {-month } \\
\text { follow-up } \\
\end{array}$ & $\begin{array}{l}\text { Similar operative } \\
\text { time }\end{array}$ \\
\hline 6 & $\begin{array}{l}\text { Helbling C, } \\
2003\end{array}$ & RT & 46 & $\begin{array}{l}\text { NBCA vs } \\
\text { abs. suture }\end{array}$ & $\begin{array}{l}\text { Favor } \\
\text { glue }\end{array}$ & Similar & Similar & $\begin{array}{c}\text { Equal } \\
\text { 3-month } \\
\text { follow-up }\end{array}$ & $\begin{array}{l}\text { Better results for } \\
\text { glue }\end{array}$ \\
\hline
\end{tabular}


Beside these advantages the use of glue in Lichtenstein repair also decreases the operative time (3 RT) or didn't prolong it (2 RT).

We identified two more RT for open inguinal hernia repair using plug and patch technique and NBCA.

Eldabe Mikhail in 2012 also reports better outcome for glue group regarding short term morbidity, chronic neuralgia and similar recurrence at 1 year follow-up in a randomized trial conducted on 198 patients, the postoperative stay was significantly shorter for the glue group (31).

Testini in 2010 compared 156 patients with inguinal hernia repaired by a plug and patch technique, the mesh fixation by sutures, human fibrin glue or n-butil-2-cyanoacrylate. Short term morbidity was lower in the glue groups compared with suture, two cases of chronic pain in the suture group, the recurrence was equal in all the groups (25).

Moreno-Egea showed that the use of another synthetic glue (n-hexyl-a-cyanoacrylate) has better results in term of pain and analgesic use while the postoperative complications and recurrence rates are the same compared with standard suture $(11,15)$.

In 2014, Sanders published a systematic review of randomized trial assessing mesh fixation in open inguinal hernia repair in which he included 12 randomized trials and 1992 patients. The overall conclusion was that suture and glues are substantially equivalent and suggested that glues may have a beneficial effect of reducing immediate post-operative pain and chronic pain (13).

\section{Minimally invasive hernia repair}

The minimally invasive procedures addressed to inguinal hernia repair (TAPP or TEP) use tacks as the first choice to fix the mesh in position or to close the peritoneal fold. Although it is less invasive than the open approach it also produces pain associated with mesh fixation. New methods of fixation were developed to decrease that complication varying from suture to glue or no-fixation at all.

In Table 3 and Table 4 we summarize the results of 7 RT comparing NCBA with other mesh fixation methods in TEP and TAPP procedures.

Considering acute pain as end-point NBCA provided superior (4 RT) or similar (3 RT) results to tacks. It has similar results with no-fixation ( 2 RT). The same thing happens in chronic pain: 3 RT report superior results and 4 similar results in the use of NBCA. Specific surgical complications are also similar in most of the studies (6 RT).

TABLE 3. RT comparing NBCA in TEP hernia repair

\begin{tabular}{|l|l|c|c|c|c|c|c|c|l|}
\hline & Author/year & Study & $\begin{array}{c}\text { Pt } \\
\text { (n) }\end{array}$ & Comparison & $\begin{array}{c}\text { Acute } \\
\text { Pain }\end{array}$ & Complications & $\begin{array}{c}\text { Chronic } \\
\text { Pain }\end{array}$ & Recurrence & Other \\
\hline 1 & Liew W, 2017 & RT & 66 & $\begin{array}{c}\text { NBCA vs } \\
\text { tacker }\end{array}$ & Similar & Similar & Similar & $\begin{array}{c}\text { Similar } \\
\text { 3-month } \\
\text { follow-up }\end{array}$ & $\begin{array}{l}\text { Elevated ESR } \\
\text { at } 3 \text { months in } \\
\text { glue group }\end{array}$ \\
\hline 3 & Shen YM, 2017 & RT & 160 & $\begin{array}{c}\text { NBCA vs } \\
\text { no-fixation }\end{array}$ & Similar & Similar & Similar & $\begin{array}{c}\text { Favor glue } \\
\text { 1-year follow- } \\
\text { up }\end{array}$ & Similar costs \\
\hline 4 & $\begin{array}{l}\text { Subwongcharoen S, } \\
2013\end{array}$ & RT & 6016 & $\begin{array}{c}\text { NBCA vs } \\
\text { suture }\end{array}$ & Similar & Similar & Similar & $\begin{array}{c}\text { Similar } \\
\text { 2 years } \\
\text { follow-up }\end{array}$ & $\begin{array}{l}\text { Less pain at } 7 \\
\text { days in glue } \\
\text { group }\end{array}$ \\
\hline
\end{tabular}

TABLE 4. RT comparing NBCA in TAPP hernia repair

\begin{tabular}{|l|l|c|c|c|c|c|c|c|l|}
\hline Author/year & Study & $\begin{array}{c}\text { Pt } \\
\text { (n) }\end{array}$ & Comparison & $\begin{array}{c}\text { Acute } \\
\text { Pain }\end{array}$ & Complications & $\begin{array}{c}\text { Chronic } \\
\text { Pain }\end{array}$ & Recurrence & Other \\
\hline Burza A, 2014 & RT & 70 & $\begin{array}{c}\text { NBCA vs } \\
\text { tacks }\end{array}$ & Favor glue & Favor glue & Favor glue & $\begin{array}{c}\text { Equal } \\
\text { 2-years } \\
\text { follow-up }\end{array}$ & $\begin{array}{l}\text { Shorter } \\
\text { hospital stays } \\
\text { for glue group }\end{array}$ \\
\hline 2 & $\begin{array}{l}\text { Wang MG, } \\
2013\end{array}$ & RT & 1027 & $\begin{array}{c}\text { NBCA vs } \\
\text { no-fixation } \\
\text { vs tacks }\end{array}$ & $\begin{array}{c}\text { Favor glue } \\
\text { and } \\
\text { no-fixation }\end{array}$ & Similar & $\begin{array}{c}\text { Favor glue } \\
\text { and } \\
\text { no-fixation }\end{array}$ & $\begin{array}{c}\text { Equal } \\
\text {-years } \\
\text { follow-up }\end{array}$ & --- \\
\hline 3 & $\begin{array}{l}\text { Brugger L, } \\
2012\end{array}$ & RT & 80 & $\begin{array}{c}\text { NBCA vs } \\
\text { tacks }\end{array}$ & Favor glue & Similar & Similar & $\begin{array}{c}\text { Similar } \\
\text { 3-years } \\
\text { follow-up }\end{array}$ & $\begin{array}{l}\text { Hypoesthesia } \\
\text { was higher in } \\
\text { tacks group }\end{array}$ \\
\hline
\end{tabular}


Recurrence rate is equal (2 RT), similar (4 RT) or favor the glue group (1 RT) in a 3 month to 3 years follow-up.

The first article that proposed the use of cyanoacrylate in TEP repair was published in 2012 and the authors noted that early postoperative pain was similar to other cases and they didn't record any early recurrence or chronic pains; in addition, an innovative instrument for glue delivery was described (18).

Garcia-Vallejo, in a case series of 61 consecutive patients (TEP procedure and NBCA mesh fixation), found that majority of patients (59\%) required low dosages of painkillers in the first 24 hours after surgery. The patients were followed for a minimum 18-month period (average 29.7 months) and no case of chronic pain or hernia recurrence was noticed (10).

There are also two more articles by MorenoEgea $(11,15)$. The author uses a similar glue ( $n$ hexyl-a-cyanoacrylate) for TEP inguinal hernia repair and he found significant differences in favor of the glue in postoperative pain and analgesic use while the morbidity and recurrence rate are similar at 1-year follow-up. He also performed a financial analysis that showed potenti- al annual savings of $€ 123,916$ by using the glue instead of suture and tackers. These articles also support the idea that the use of glue instead of mechanical fixation is beneficial to postoperative outcome.

After all the papers were reviewed we can say that no studies showed the inferiority of glue over the other methods of fixation considering all four postoperative outcome (acute pain, complication, chronic pain and recurrence). Furthermore, synthetic glue fixation has better results in terms of acute and chronic pain for both open and minimally-invasive surgical procedures for inguinal hernia repair.

\section{CONCLUSIONS}

Synthetic glue mesh fixation for inguinal hernia is not a very popular or commonly-used method of fixation over the world.

It has been proved that it is a safe and effective method of mesh fixation both in open or minimally invasive inguinal hernia repair and significantly decreases the postoperative acute and chronic pain.

\section{REFERNCES}

1. J. Burcharth, M. Pedersen, T. Bisgaard, C. Pedersen, and J. Rosenberg. Nationwide Prevalence of Groin Hernia Repair. PLoS One, vol. 8, no. 1, p. e54367, Jan. 2013.

2. E.M. Beller et al. Guidelines and Guidance PRISMA for Abstracts: Reporting Systematic Reviews in Journal and Conference Abstracts, for the PRISMA for Abstracts Group.

3. W. Liew, Y.Y. Wai, N.R. Kosai, H.S. Gendeh. Tackers versus glue mesh fixation: an objective assessment of postoperative acute and chronic pain using inflammatory markers. Hernia, vol. 21, no. 4, pp. 549-554, Aug. 2017.

4. Y.-M. Shen, Y.-T. Liu, J. Chen, L. Sun. Efficacy and safety of NBCA (n-butyl-2cyanoacrylate) medical adhesive for patch fixation in totally extraperitoneal prosthesis (TEP): a prospective, randomized, controlled trial. Eur. Rev. Med. Pharmacol. Sci., vol. 21, no. 4, pp. 680-686, 2017.

5. C. Hoyuela et al. Randomized clinical trial of mesh fixation with glue or sutures for Lichtenstein hernia repair. Br. J. Surg., vol. 104, no. 6, pp. 688-694, May 2017.

6. M. Matikainen, J. Kössi, S. Silvasti, T. Hulmi, H. Paajanen. Randomized Clinical
Trial Comparing Cyanoacrylate Glue Versus Suture Fixation in Lichtenstein Hernia Repair: 7-Year Outcome Analysis. World J. Surg., vol. 41, no. 1, pp. 108-113, Jan. 2017.

7. S.A. Antoniou, G. Köhler, G.A. Antoniou, F.E. Muysoms, R. Pointner, F.-A. Granderath. Meta-analysis of randomized trials comparing nonpenetrating vs mechanical mesh fixation in laparoscopic inguinal hernia repair. Am. J. Surg., vol. 211, no. 1, p. 239-249.e2, Jan. 2016.

8. K. Jani. Randomised controlled trial of n-butyl cyanoacrylate glue fixation versus suture fixation of mesh in laparoscopic totally extraperitoneal hernia repair. J. Minim. Access Surg., vol. 12, no. 2, p. 118, 2016.

9. K. Rönkä et al. Randomized Multicenter Trial Comparing Glue Fixation, Self-gripping Mesh, and Suture Fixation of Mesh in Lichtenstein Hernia Repair (FinnMesh Study). Ann. Surg., vol. 262, no. 5, pp. 714-720, Nov. 2015.

10. L. Garcia-Vallejo, I. Couto-Gonzalez, P. Concheiro-Coello, B. Brea-Garcia, A. Taboada-Suarez. Cyanoacrylate surgical glue for mesh fixation in laparoscopic total extraperitoneal hernia repair. Surg. Laparosc. Endosc. Percutan. Tech., vol. 24, no. 3, pp. 240-3, Jun. 2014.

11. A. Moreno-Egea. Is it possible to eliminate sutures in open (lichtenstein technique) and laparoscopic (totally extraperitoneal endoscopic) inguinal hernia repair? A randomized controlled trial with tissue adhesive (n-hexyl-a-cyanoacrylate). Surg. Innov., vol. 21, no. 6, pp. 590-9, Dec. 2014.

12. A. Burza, R. Avantifiori, R. Curinga, E. Santini, P. Delle Site, F. Stipa. Comparison between two different mesh fixation methods in laparoscopic inguinal hernia repair: tacker vs. Synthetic cyanoacrylate glue.). Minerva Chir., vol. 69, no. 6, pp. 321-329, Dec. 2014.

13. D.L. Sanders, S. Waydia. A systematic review of randomised control trials assessing mesh fixation in open inguinal hernia repair. Hernia, vol. 18, no. 2 , pp. 165-76, Apr. 2014.

14. S. Subwongcharoen, K. Ruksakul. A randomized controlled trial of staple fixation versus $\mathrm{N}$-butyl-2-cyanoacrylate fixation in laparoscopic inguinal hernia repair. J. Med. Assoc. Thai., vol. 96 Suppl 3, pp. S8-13, Mar. 2013.

15. A. Moreno-Egea. Is sutureless hernia repair a safe option for treating abdominal 
wall hernias? A prospective study with a synthetic tissue adhesive (n-hexyl-alphacyanoacrylate)). Cirugía española, vol. 91, no. 4, pp. 243-9, Apr. 2013.

16. M. Wang, M. Tian, X. Zhao, Y. Nie, J. Chen, Y. Shen. Effectiveness and safety of n-butyl-2-cyanoacrylate medical adhesive for noninvasive patch fixation in laparoscopic inguinal hernia repair. Surg. Endosc., vol. 27, no. 10, pp. 3792-8, Oct. 2013.

17. A. Eldabe Mikhail, A. Palomo Luquero J.F. Reoyo Pascual, J.L. Seco Gil.

Prosthetic material fixation in open inguinal hernioplasty: suture vs. synthetic glue). Cir. Esp., vol. 90, no. 7, pp. 446-52.

18. S.-A. Treepongkaruna, S. Subwongcharoen. Novel technique of mesh fixation with cyanoacrylate in totally extraperitoneal laparoscopic hernia repair: early experience. J. Med. Assoc. Thai., vol. 95 Suppl 3, pp. S98-101, Mar. 2012.

19. S. Dąbrowiecki, S. Pierściński, W. Szczęsny. The Glubran 2 glue for mesh fixation in Lichtenstein's hernia repair: a double-blind randomized study. Wideochirurgia i inne Tech. maloinwazyjne = Videosurgery other miniinvasive Tech., vol. 7, no. 2, pp. 96-104, Jun. 2012.

20. Y. Shen, W. Sun, J. Chen, S. Liu, M. Wang. NBCA medical adhesive (n-butyl-2-cyanoacrylate) versus suture for patch fixation in Lichtenstein inguinal herniorrhaphy: a randomized controlled trial. Surgery, vol. 151, no. 4, pp. 550-5, Apr. 2012.
21. L. Brügger, M. Bloesch, R. Ipaktchi, A. Kurmann, D. Candinas, G. Beldi. Objective hypoesthesia and pain after transabdominal preperitoneal hernioplasty: a prospective, randomized study comparing tissue adhesive versus spiral tacks. Surg. Endosc., vol. 26, no. 4, pp. 1079-85, Apr. 2012.

22. J.F. Kukleta, C. Freytag, M. Weber. Efficiency and safety of mesh fixation in laparoscopic inguinal hernia repair using n-butyl cyanoacrylate: long-term biocompatibility in over 1,300 mesh fixations. Hernia, vol. 16, no. 2, pp. 153-62, Apr. 2012.

23. C. Kim-Fuchs, E. Angst, S. Vorburger, C. Helbling, D. Candinas, R. Schlumpf. Prospective randomized trial comparing sutured with sutureless mesh fixation for Lichtenstein hernia repair: long-term results. Hernia, vol. 16, no. 1, pp. 21-7, Feb. 2012.

24. H. Paajanen, J. Kössi, S. Silvasti, T. Hulmi, T. Hakala. Randomized clinical trial of tissue glue versus absorbable sutures for mesh fixation in local anaesthetic Lichtenstein hernia repair. Br. J. Surg., vol. 98, no. 9, pp. 1245-51, Sep. 2011.

25. M. Testini, G. Lissidini, E. Poli, A. Gurrado, D. Lardo, G. Piccinni. A single-surgeon randomized trial comparing sutures, N-butyl-2-cyanoacrylate and human fibrin glue for mesh fixation during primary inguinal hernia repair. Can. $J$. Surg., vol. 53, no. 3, pp. 155-60, Jun. 2010.

26. F. Agresta et al. Lightweight partially absorbable monofilament mesh (polypropylene/poliglecaprone 25) for TAPP inguinal hernia repair: initial experience. Surg. Laparosc. Endosc. Percutan. Tech., vol. 17, no. 2, pp. 91-4, Apr. 2007.

27. W. Nowobilski, M. Dobosz, T. Wojciechowicz, L. Mionskowska. Lichtenstein inguinal hernioplasty using butyl-2-cyanoacrylate versus sutures. Preliminary experience of a prospective randomized trial. Eur. Surg. Res., vol. 36, no. 6 , pp. 367-70.

28. C. Helbling, R. Schlumpf. Sutureless Lichtenstein: first results of a prospective randomised clinical trial. Hernia, vol. 7, no. 2, pp. 80-4, Jun. 2003.

29. I.C. Jourdan, M.E. Bailey. Initial experience with the use of $\mathrm{N}$-butyl 2-cyanoacrylate glue for the fixation of polypropylene mesh in laparoscopic hernia repair. Surg. Laparosc. Endosc., vol. 8, no. 4, pp. 291-3, Aug. 1998.

30. T.H. Group. International guidelines for groin hernia management. Hernia, vol. 22, no. 1, pp. 1-165, Feb. 2018.

31. A. Eldabe Mikhail, A. Palomo Luquero, J.F. Reoyo Pascual, J.L. Seco Gil. Fijación del material protésico en la hernioplastia inguinal abierta: sutura vs. cola sintética. Cirugía Española, vol. 90, no. 7, pp. 446-452, Aug. 2012. 